\title{
Determinants of Overweight Among Government Employees in Gibe District, Hadiya Zone, Southern Ethiopia: A Case Control Study
}

\author{
Adinew Nega ${ }^{1} \quad$ Tilahun Beyene ${ }^{2}$ \\ 1.Gibe District Health office, Ethiopia \\ 2.Wolaita Sodo University, School of Public Health Department of Epidemiology and Biostatistics, Ethiopia
}

\begin{abstract}
Background: Overweight in Africa have been attributed to demographic and nutritional changes that have resulted from urbanization, sedentary lifestyles and increased caloric intake without much physical activities. This has put populations at an increased risk of chronic diseases. The purpose of the present study was to assess determinants of overweight among government employees.

Methods: A case control study was conducted among government employees in Gibe district. A total of 206 employees (51 cases and 155 controls) were selected by using simple random sampling technique. Cases were whose body mass index (BMI) greater than or equal to $25 \mathrm{~kg} / \mathrm{m}^{2}$, whereas, controls were whose body mass index greater than or equal to $18.5 \mathrm{~kg} / \mathrm{m}^{2}$ and less than $25 \mathrm{~kg} / \mathrm{m}^{2}$. Structured questionnaire was used to collect data on risk factors of overweight. Data entry and cleaning were done by using Epi-data version 3.1 and exported to SPSS version 20 for analysis. Bivariate and multivariable binary Logistic regression was used to identify predictors of overweight.

Results: A total of 206 government employees were interviewed, male gender participants were 3.5 times more likely to develop overweight compared to females (AOR: 3.5; 95\%CI: 1.044-11.957), old age group 45+ years responders were 6.3 times more likely to develop overweight compared to age group 20-34years (AOR: 6.3; 95\% CI: 1.503-26.621) and employees who were low level physical activity 4.6 times more likely to develop overweight compared to those having high level physical activity(AOR: 4.6, 95\%CI: 1.100-19.119).

Conclusions and recommendation:

Government employees of Gibe District had old age group, male gender and low physical activity that lead to increased risk of overweight. These are modifiable and non- modifiable risk factors; therefore increased awareness about physical activity will be effective control measure.
\end{abstract}

Keywords: overweight, government employees, determinants

DOI: $10.7176 / \mathrm{JHMN} / 60-03$

Publication date:March $31^{\text {st }} 2019$

\section{Introduction}

The human body needs energy to function and food is the source of this energy. The body stores excess energy mainly in the form of fats $(1,2)$.

Among workers, health problems such as overweight appear to be associated with the type of work performed and with the working environment $(1,2)$. Prevalence rates of overweight varying from $36.6 \%$ to $38.9 \%$ and of obesity varying from $12.7 \%$ to $17.0 \%$ have been observed in technical and administrative staff working at public institutions in Brazil (3).

In 2010 , overweight and obesity were estimated to cause 3.4 million deaths, $3.9 \%$ of years of life lost, and $3 \cdot 8 \%$ of disability-adjusted life-years (DALYs) worldwide (4). Africa is experiencing a shift from underweight to overweight along with rapid socioeconomic and nutritional transition particularly in their urban population. This transformation comes with increased access to energy-dense foods and less strenuous jobs resulting into many people having a positive energy balance and hence becoming overweight or obese $(5,6)$.

A substantial decrease in physical activity and energy expenditure, coupled with an increase in energy intake has been reported as the main factors promoting overweight(7). The World Health Organization reported that the principal reason for this excess weight problem is an energy imbalance between calories consumed and calories expended. Increasing foods intake of high energy and decreasing in physical activity, due to increasing urbanization, changing modes of transportation and sedentary working environments account for this energy imbalance (8).

Perception of body-weight status plays an important role in weight management (9) and underestimation of body-weight can be a risk factor for obesity in some people (10). On the other hand, overestimation of the weight by underweight or normal weight subjects can be a risk factor for unhealthy weight control practices (11) and may cause eating disorders (12).

In western countries, about two thirds of adults in the United States and United Kingdom are overweight or obese and at least one quarter is obese $(13,14)$. High prevalence of obesity was also found among employees at 
one of the South Africa diamond mine, prevalence was $45 \%$ and $32 \%$ among females and males respectively (15). In Addis Ababa, EDHS 2011 report showed that round 20\% of women and 12.4\% of men are overweight or obese (BMI $\geq 25 \mathrm{~kg} / \mathrm{m} 2$ ) (16). Furthermore, there are reports of a more rapid rise in the prevalence of obesity in developing countries compared to developed countries (17).

According to WHO, in many developing countries, research and investment in health has been mainly devoted to infectious diseases, despite the growing need to address chronic diseases with more effort and resources (18). Deaths from infectious diseases, maternal and perinatal conditions and nutritional deficiencies combined are projected to decline by $3 \%$ over the next 10 years, while during the same time; deaths due to chronic diseases are projected to increase by $17 \%$. As a result, it is estimated that of the projected 64 million deaths worldwide in 2015 , 41 million (64\%) will result from chronic diseases unless urgent action is taken (19).

Once associated only with high-income countries, overweight and obesity are now also prevalent in low and middle-income countries (20). It is currently estimated that as much as $20-50 \%$ of urban populations in Africa are classified as either overweight or obese and that by 2025 , three quarters of the obese population worldwide will be in non-industrialized countries (21). WHO had declared overweight as one of the top ten health risks in the world and one of the top five in developed nations (22). This is therefore an area that needs attention in mitigating health related conditions resulting from long hours of sitting in the office, treating and preventing overweight among employees could result in health gains and possible cost reductions due to decreased health care use and absenteeism.

\section{Methods and Materials \\ Study area and period}

Gibe District is found in Hadiya zone SNNPRs of Ethiopia. It is located 262Km away from Addis Ababa to southern part of Ethiopia, $226 \mathrm{~km}$ from regional city Hawassa to southwest. According to 2007 Ethiopia census projection, the District has total of 135,503 populations reside (23). The District has 22 kebeles. It has both Kolla (lowland), woinadega (midland) and Dega (highland) climatic zones. It has 23 total number of institutions, where a total number of government employees of the district is 1597 of which $557(35 \%)$ are females. The study was conducted in Gibe District from, February to March, 2016.

\section{Study design:}

Institutional based case control study was conducted

\section{Population}

Sources population:

All government employees working in Gibe District

\section{Study population:}

Cases: all government employees in selected institutions who were overweight

Controls: all government employees in selected institutions who were normal body weight

Cases definition: cases were those workers who had body mass index greater than or equal to $25 \mathrm{~kg} / \mathrm{m}^{2}$ $\left(\mathrm{BMI} \geq 25 \mathrm{~kg} / \mathrm{m}^{2}\right)$

Controls definition: controls were those workers who had body mass index greater than or equal to $18.5 \mathrm{~kg} / \mathrm{m}^{2}$ and lessthan $25 \mathrm{~kg} / \mathrm{m}^{2}$

\section{Inclusion and Exclusion criteria:}

\section{Inclusion criteria:}

Cases: we included all selected overweight workers

Controls: we included all selected normal body weight workers

Exclusion criteria:

Cases/controls: we excluded pregnant female staffs and critically ill during data collection.

Sample size determination and sampling techniques/procedures

The sample size was determined by using EPI INFO version 7, software of two population proportion formula by assumption of $95 \%$ confidence interval, $80 \%$ power, $10 \%$ non-response, Ratio (normal: overweight) $=3: 1, \mathrm{P} 1=$ percent of controls exposed

$$
\begin{aligned}
& \mathrm{n}_{1}=\frac{\left[Z_{\mathrm{a} / 2} \sqrt{\overline{\bar{x}_{1}}(1+1 / \lambda)}+Z_{\beta} \sqrt{\mathrm{p}_{1} \mathrm{q}_{1}+\mathrm{p}_{2} \mathrm{q}_{2} / \lambda}\right]^{2}}{\Delta^{2}} \\
& \quad \text { Where } \mathrm{n}_{2}=\mathrm{n}_{1} \lambda, \quad \bar{p}=\left(\mathrm{p}_{1}+\lambda_{\mathrm{p} 2}\right) /(1+\lambda)
\end{aligned}
$$

$\mathrm{P} 2=$ percent of cases with exposure, $\mathrm{Z} \alpha / 2=$ Standard normal variable at confidence level of $95 \%$ (1.96)

Was calculated on Epi-Info soft ware using factors associated with overweight by taking study findings from 
previous study(24). (Table 1)

Table : 1 sample size calculation on Epi-Info soft ware using factors associated with overweight, 2016

\begin{tabular}{|l|l|l|l|l|l|l|l|}
\hline Factors & $\begin{array}{l}\text { Percent of } \\
\text { controls } \\
\text { exposed }\end{array}$ & $\begin{array}{l}\text { Percent of } \\
\text { cases exposed }\end{array}$ & Ratio & OR & $\begin{array}{l}\text { Sample } \\
\text { size }\end{array}$ & $\begin{array}{l}\text { Non- } \\
\text { response } \\
\text { rate }\end{array}$ & $\begin{array}{l}\text { Final } \\
\text { sample } \\
\text { size }\end{array}$ \\
\hline physical active & $59.57 \%$ & $33.4 \%$ & $3: 1$ & 0.34 & 168 & $10 \%$ & 185 \\
\hline $\begin{array}{l}\text { Alcohol } \\
\text { consumption }\end{array}$ & $48.75 \%$ & $74.1 \%$ & $3: 1$ & 3.0 & 175 & $10 \%$ & 193 \\
\hline Married & $36.84 \%$ & $61.6 \%$ & $3: 1$ & 2.75 & 187 & $10 \%$ & 206 \\
\hline
\end{tabular}

Finally, the maximum sample size calculated using married was $=206$; which implies 51 cases and 155 controls

\section{Sampling procedure:}

From twenty three institutions, thirteen institutions were selected by simple random sampling technique (lottery method).Census was done on selected institutions to know the number of cases and controls. During census 68 cases and 654 controls were identified. All cases and controls were registered on different register book before data collection. Finally, by using simple random sampling technique (lottery method) study subjects were selected.

\section{(Figure 1)}

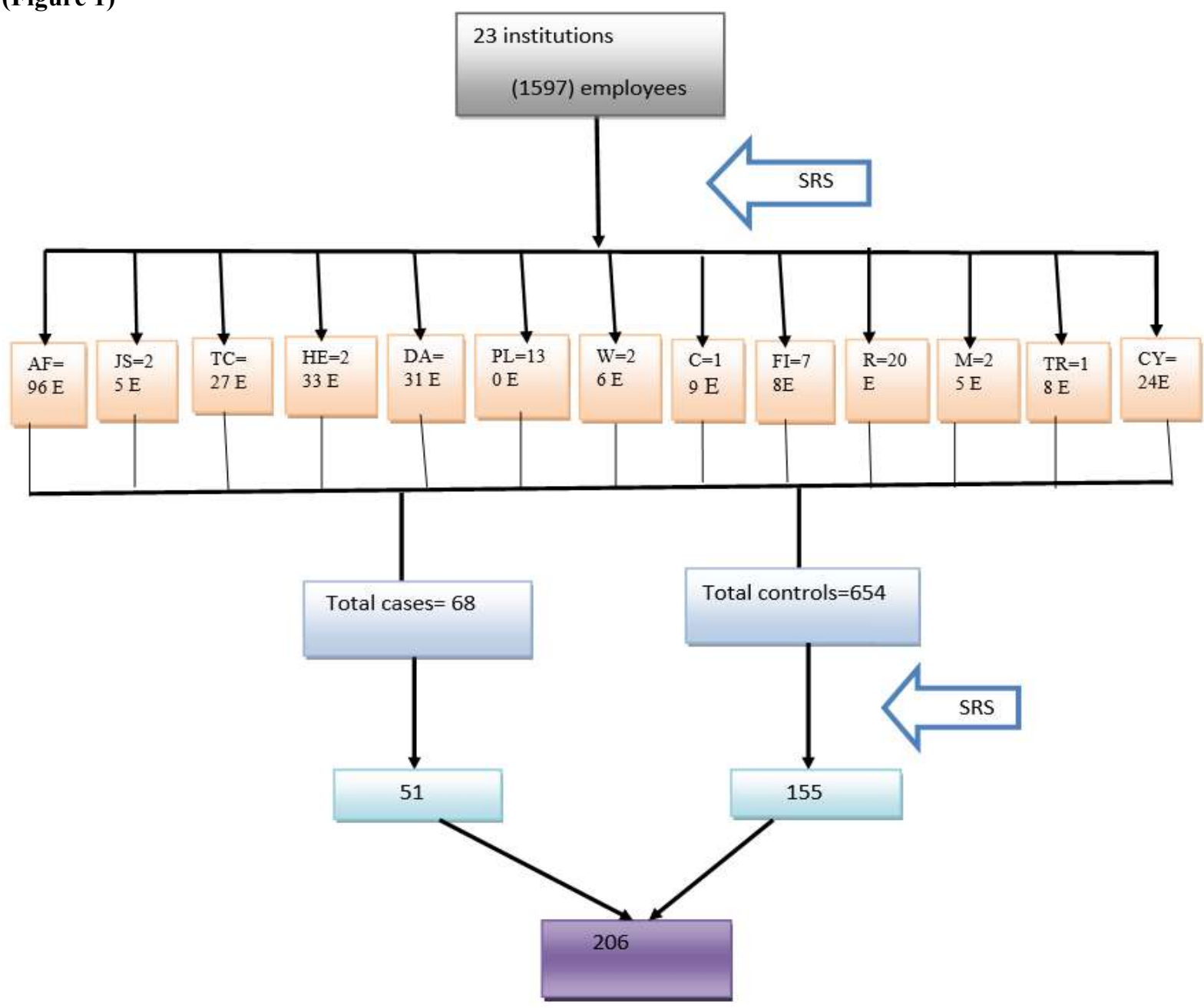

Key

E=Employees

$\mathrm{AF}=$ Agriculture, $\mathrm{JS}=$ Justice, $\mathrm{TC}=$ Transport communication,

$\mathrm{HE}=$ Health, $\mathrm{DA}=$ Gibe District administrative office $\mathrm{PL}=$ Polices

$\mathrm{W}=$ Water resource, $\mathrm{C}=$ Civil service, $\mathrm{FI}=$ Finance, $\mathrm{R}=$ Revenues $\mathrm{M}=$ Municipality, $\mathrm{TR}=\mathrm{Trade}$ and investment, $\mathrm{CY}=$ Child and youth offices were selected institutions (752 employees)

Figure 1: Schematic sampling technique for selection of normal and overweight employees 


\section{Study variables:}

Dependent variables

Body weight status (normal or overweight)

\section{Independent variables}

Socio- demographic and economic variables

age, sex, marital status, religion, education level, monthly salary,

works experience and residences

Risk perception

Behavior; Smoking, Alcohol, diet, Physical activities

\section{Data collection procedures and Instrument}

Data were collected using the structured questionnaire which was adapted from "WHO Stepwise approach to chronic disease risk factor surveillance" and from different literatures. Weight was measured using calibrated UNICEF Seca digital weighing scale (Germany) in kilogram (kg).

The measurements were taken once from each respondent and the records were made to the nearest $0.1 \mathrm{~kg}$, without shoes and light clothes. Height was measured using Stadiometer (Seca, Germany)in centimeter $(\mathrm{cm})$ in standing position on bare feet, with heels together, and buttocks and back touching the meter rule. The measurements were taken once from each respondent and the records were made to the nearest $0.1 \mathrm{~cm}$. The questionnaire included socio demographic and economic characteristics such as age, sex, educational level, monthly salary and years of service, behavioral factors such as tobacco use, alcohol use, dietary habit and physical activity and risk perception.

The Questionnaire was first prepared in English and then translated into Amharic and again it was translated back to English to check for consistency. Three diploma nurse interviewers and one Bachelor of Science nurse supervisor was collected the data. Data collectors were trained for three days on questions included in the questionnaire, on interviewing techniques, purpose of the study, and importance of privacy, discipline and approach to the interviewees and confidentiality of the respondents. Before conducting the main study, pretest was carried out of the selected institutions which were not included in the main study. Based on the result, data collectors were reoriented and the questionnaires were modified as necessary.

\section{Data quality control}

To ensure the quality of data to be gathered from the study subjects, a range of mechanisms was employed to address major areas of bias introduction during the data collection process. First, the questionnaire was pre- tested on five present employees in out of selected institutions on similar settings and necessary modification was made based on the nature of gaps identified in the questionnaire. Data collectors were trained on how to gather the appropriate information, procedures of data collection techniques and the whole contents and subject matter of the questionnaire. A day today on site supervision by the researcher was carried out during the whole period of data collection. At the end of each day, the questionnaire was reviewed and cross checked for completeness and consistency by the investigator and corrective discussion was under taken with all the data collectors. Data were cleaned and edited after it was entered in to the software.

\section{Data Processing and Analysis}

Data were coded, entered, cleaned by using Epi-data version 3.1 and exported to SPSS version 20.0 for analysis. Frequencies and cross tabulations were used to summarized descriptive statistics. Tables used for data presentation. The association between outcome variable and explanatory variables were assessed first bivariate analysis. In Bivariate logistic regression, the variables with $\mathrm{P}$-value $<0.25$ was candidates to multivariable Logistic regression. Then the multivariable logistic regression model was performed to determine the effect of various factors on the outcome variable and to control confounding. The model fitness for variables was assessed by Hosmer-Lemeshow Goodness of fit test. Multicollinearity among independently associated variables was checked by Multicollinearity diagnostic test VIF but it was not detected. The results were presented using adjusted Odds ratios with ninety five percent confidence intervals. Statistical significance declared at $\mathrm{P}$-value $<0.05$.

\section{Ethical considerations}

Prior to data collection appropriate ethical clearance was obtained from the ethical clearance committee College of Health Sciences of the Jimma University. Formal letter of permission was produced from administrative bodies of the zone to the study district. Letter of cooperation from each institution administrators was obtained. Finally verbal consent was requested from every study participant included in the study during data collection time after explaining the objectives of the study. Confidentiality assured for the information provided. 


\section{Operational definitions}

Physical activity: We collected data on the type of physical activity. We divided into three categories namely activities as a part of individual work, travel to and from places (walk/cycling) and recreational activities. Both work related and recreational activities were classified as vigorous intensity and moderate intensity activities.

'Vigorous intensity activity' was one which causes large increases in breathing or heart rate and was carried out for at least 10 minutes continuously.

'Moderate intensity activity' was one which causes small increases in breathing or heart rate and was carried out for at least 10 minutes continuously.

Recreational (leisure) activities: We collected data about time spent at sports and fitness activities.

Level of physical activity was computed using metabolic equivalent based on the time spent for work, transportation and recreation. It provides 3 level physical activities.

Low level physical activity was a combination of walking, moderate or vigorous physical activities achieving a $<600$ MET-minutes/week.

Moderate level physical activity was a combination of walking, moderate or vigorous activities achieving 6003000 MET-minutes/week.

High level physical activity was a combination of walking, moderate or vigorous activities achieving $\geq 3000$ MET-minutes/week

Time spending on sitting: We collected data about sitting or reclining at work, at home, getting to and from places, or with friends including time spent( sitting at a desk sitting with friends, traveling in a car, bus, reading, playing card or watching television), but not included time spent sleeping.

Body weight status: BWS are categorized as normal weight (BMI greater or equal to $18.5 \mathrm{~kg} / \mathrm{m}^{2}$ and less than $25 \mathrm{~kg} / \mathrm{m}^{2}$ ) or overweight (BMI greater or equal to $25 \mathrm{~kg} / \mathrm{m}^{2}$ ).

Smoking/Tobacco use: Current smoker were one who was smoking tobacco at the time of data collection. Daily smokers were one who was smoking any tobacco products daily.

Alcohol Consumption: Ever consumers were one who was drinking any alcohol product. Consumption of fruits and vegetables: We collected data on the frequency of consumption of fruits and vegetables in a week. We considered a person to be at risk if the consumption of fruits and vegetables was less than 5 days/week

Risk perception: From total of six dichotomized questions, 1 for correct, 0 for incorrect answer about body weight, whose answer medium score and above were taken as having low risk perception and below medium score, were taken as having high risk perception.

Typical week: means a week when a person has eaten fruit or vegetable and not an average over a period.

\section{Results}

Socio-demographic and economic characteristics of the respondents

A total of 206(51 cases and 155 controls) government employees were interviewed. Of all study participants $24(47.1 \%)$ of cases and $97(62.6 \%)$ of controls were found in the age group 20-34 years and with ranges from 2058 years. The median age of study participants were 34 years $(\mathrm{SD} \pm 8.25)$ and 31years $(\mathrm{SD} \pm 6.78)$ of cases and controls, respectively. With regarding to marital status, 31(60.8\%) of cases and $69(44.5 \%)$ of controls were married. Majority of the participants, $(82.2 \%)$ of cases and $(92.9 \%)$ of controls were protestants in religion.

Among the study participants, $39(76.5 \%)$ of cases and $140(90.3 \%)$ of controls were Hadiya in ethnicity; whereas, $6(11.8 \%)$ of cases, $7(4.5 \%)$ of controls and $6(11.8 \%)$ of cases, $8(5.2 \%)$ of controls were Kanbata and Gurage in ethnicity, respectively. The gender of study participants, $41(80.4 \%)$ of cases and $96(61.9 \%)$ of controls were male gender. Pertaining to educational status of the study subjects, $22(43.1 \%)$ of cases and77 (49.7\%) of controls were completed University/postgraduate degree. Majority of the participants, $(86.3 \%)$ of cases and $(76.1 \%)$ of controls were urban in residences. Of all study participants, 20(39.2\%) of cases and 83(53.5\%) of controls were earned (1000-2999 ETB) monthly salary. Majority of study participants, $(64.7 \%)$ of cases and (72.9\%) of controls had been with the institution for less than 10 years (Table 2) 
Table: 2 Socio-demographic and economic distribution among the study participants in Gibe district, Hadiya zone, Southern Ethiopia, 2016.

\begin{tabular}{|c|c|c|c|c|c|}
\hline \multirow[t]{2}{*}{ Variables } & \multirow[t]{2}{*}{ Categories } & $\begin{array}{l}\text { Cases } \\
(n=51)\end{array}$ & $\begin{array}{l}\text { Controls } \\
(n=155)\end{array}$ & \multirow[t]{2}{*}{$\begin{array}{l}\text { Crude OR } \\
(95 \% \text { CI })\end{array}$} & \multirow[t]{2}{*}{$\begin{array}{l}\text { p- } \\
\text { value }\end{array}$} \\
\hline & & No $(\%)$ & No $(\%)$ & & \\
\hline \multirow{3}{*}{$\begin{array}{lll}\text { Age group in } \\
\text { years }\end{array}$} & $20-34$ & $24(47.1 \%)$ & $97(62.6 \%)$ & 1 & \\
\hline & $35-44$ & $18(35.3 \%)$ & $50(32.3 \%)$ & $1.5(0.723-2.930)$ & 0.294 \\
\hline & $\geq 45$ & $9(17.6 \%)$ & $8(5.1 \%)$ & $\begin{array}{l}4.6(1.588- \\
13.019)^{*}\end{array}$ & 0.005 \\
\hline \multirow[t]{2}{*}{ Sex } & Male & $41(80.4 \%)$ & $96(61.9 \%)$ & $2.5(1.174-5.407)^{*}$ & 0.018 \\
\hline & Female & $10(19.6 \%)$ & $59(38.1 \%)$ & 1 & \\
\hline \multirow[t]{2}{*}{ Residence } & Urban & $44(86.3 \%)$ & $140(76.1 \%)$ & $1.48(0.569-3.874)$ & 0.419 \\
\hline & Rural & $7(13.7 \%)$ & $15(9.7 \%)$ & 1 & \\
\hline \multirow[t]{2}{*}{ Religion } & Protestant & $45(88.2 \%)$ & $144(92.9 \%)$ & 1 & \\
\hline & Orthodox & $6(11.8 \%)$ & $11(7.1 \%)$ & $\begin{array}{l}1.745(0.611- \\
4.986)\end{array}$ & 0.298 \\
\hline \multirow[t]{2}{*}{ Marital status } & Single & $20(39.2 \%)$ & $86(55.5 \%)$ & 1 & \\
\hline & Married & $31(60.8 \%)$ & $69(44.5 \%)$ & $1.9(1.013-3.683)^{*}$ & 0.045 \\
\hline \multirow{4}{*}{$\begin{array}{l}\text { Monthly salary } \\
\text { (ETB) }\end{array}$} & $<1000$ & $5(9.8 \%)$ & $15(9.7 \%)$ & 1 & \\
\hline & $1000-2999$ & $20(39.2 \%)$ & $83(53.5 \%)$ & $\begin{array}{l}0.723(0.235- \\
2.224)\end{array}$ & 0.571 \\
\hline & $3000-4999$ & $17(33.3 \%)$ & $44(28.4 \%)$ & $1.16(0.365-3.685$ & 0.802 \\
\hline & $\geq 5000$ & $9(17.6 \%)$ & $13(8.4 \%)$ & $2.07(0.554-7.788)$ & 0.278 \\
\hline \multirow[t]{3}{*}{ Educational level } & High school & $5(9.8 \%)$ & $17(11.0 \%)$ & $1.03(0.341-3.105)$ & 0.959 \\
\hline & College & $24(47.1 \%)$ & $61(39.3 \%)$ & $1.4(0.705-2.688)$ & 0.349 \\
\hline & $\begin{array}{l}\text { University/ } \\
\text { postgraduate }\end{array}$ & $22(43.1 \%)$ & $77(49.7 \%)$ & 1 & \\
\hline \multirow[t]{2}{*}{ Year of services } & $<10$ & $33(64.7 \%)$ & $113(72.9 \%)$ & 1 & \\
\hline & $\geq 10$ & $18(35.3 \%)$ & $42(27.1 \%)$ & $\begin{array}{l}1.468(0.747- \\
2.882)\end{array}$ & 0.265 \\
\hline
\end{tabular}

*= $\mathrm{P}<0.05$ (significance level), $1=$ Reference

Risk perception and behavioral characteristics of the respondents

Of all study participants, $26(51.0 \%)$ of cases and 65(41.9\%) of controls were high risk perception about their body weight. Among the study participants, $11(21.6 \%)$ of cases and $2(1.3 \%)$ of controls were currently smoker any tobacco products. From the study participants, $6(11.8 \%)$ of cases and $16(10.3 \%)$ of controls were ever smoking in the past.

Of all the study participants, $20(39.2 \%)$ of cases and $43(27.7 \%)$ of controls were exposed to tobacco smoking at home or workplace. Of all study participants, $18(35.3 \%)$ of cases and $42(27.9 \%)$ of controls were ever consumed an alcoholic drink. In terms of frequency of alcohol consumption in the 12 months preceding the study, 3(16.7\%) of cases and $7(16.7 \%)$ of controls were consumed daily, whereas, $7(38.9 \%)$ of cases and $14(33.3 \%)$ of controls were consumed 1-4 days a week and 5(27.8\%) of cases and 10(23.8\%) of controls were consumed 1-3 days a week.

The intake of fruits and vegetables among the study participants, majority of the study participants $(88.2 \%)$ of cases and (69.7\%) of controls were received less than five days usually ate fruit in a typical week. Almost all of study participants, $(97.9 \%)$ of cases and $(94.8 \%)$ of controls were received less than five servings of fruit per day the ate on one of those days in a week. Of all study of participants, 46(90.2\%) of cases and 121(78.1\%) of controls were received less than five days ate vegetables in a typical week. Most of study participants, $(88.9 \%)$ of cases and $(78.3 \%)$ of controls were received less than five servings of vegetables ate on one of those days in a week. Commonly used oil or fat for the preparation of meals as reported by the study participants, 22(43.1\%) of cases and 65(41.9\%) of controls were margarine.

With regard to the experience of work related vigorous physical activity, of the participants $6(27.8 \%)$ of cases and $23(14.8 \%)$ of controls were engaged in work-related vigorous activity of at least 10 minutes per day. Of the study participants $14(27.5 \%)$ of cases and $35(22.6 \%)$ of controls were engaged in work-related moderate activity of at least 10 minutes per day. Among the study participants $25(49.0 \%)$ of cases and $87(56.1 \%)$ of controls were practiced walking or bicycle riding as usual physical activity.

Of the study participants, $8(22.9 \%)$ of cases and $30(19.4 \%)$ of controls were engaged in recreational-related vigorous activity of at least 10 minutes per day. In terms of time spending on sitting, 41(80.4\%) of cases and $107(69.0 \%)$ of controls were reported on sitting greater than or equal to 10 hour per day. Of the study participants, 
$19(67.9 \%)$ of cases and $32(28.1 \%)$ of controls were low level physical activity or $<600$ MET -minutes per week. (Table 3)

Table: 3 Risk Perception and behavioral characteristics of the study participants in Gibe district, Hadiya zone, Southern Ethiopia 2016

\begin{tabular}{|c|c|c|c|c|c|}
\hline \multirow[b]{2}{*}{ Variables } & \multirow[t]{2}{*}{ Categories } & $\begin{array}{l}\text { Cases } \\
(n=51)\end{array}$ & $\begin{array}{l}\text { Controls } \\
(n=155)\end{array}$ & \multirow[t]{2}{*}{$\begin{array}{l}\text { Crude OR } \\
(95 \% \text { CI })\end{array}$} & \multirow{2}{*}{$\begin{array}{l}\text { p- } \\
\text { value }\end{array}$} \\
\hline & & No $(\%)$ & No $(\%)$ & & \\
\hline \multirow{2}{*}{ Risk perception } & High & $26(51.0 \%)$ & $65(41.9 \%)$ & $1.44(0.763-2.717)$ & 0.260 \\
\hline & Low & $25(49.0 \%)$ & $90(58.1 \%)$ & 1 & \\
\hline \multirow[t]{2}{*}{ In the past, did you ever smoke } & Yes & $6(11.8 \%)$ & $16(10.3 \%)$ & $1.2(0.428-3.138)$ & 0.773 \\
\hline & No & $45(88.2 \%)$ & $139(89.7 \%)$ & 1 & \\
\hline \multirow{2}{*}{$\begin{array}{l}\text { exposed to tobacco smoking at } \\
\text { your home or workplace }\end{array}$} & Yes & $20(39.2 \%)$ & $43(27.7 \%)$ & $1.7(0.866-3.261)$ & 0.125 \\
\hline & No & $31(60.8 \%)$ & $112(72.3 \%)$ & 1 & \\
\hline \multirow{2}{*}{$\begin{array}{l}\text { ever consumed an alcoholic } \\
\text { drink }\end{array}$} & Yes & $18(35.3 \%)$ & $42(27.1 \%)$ & $1.5(0.747-2.882)$ & 0.265 \\
\hline & No & $33(64.7 \%)$ & $113(72.9 \%)$ & 1 & \\
\hline \multirow{2}{*}{$\begin{array}{l}\text { Consumed an alcoholic drink } \\
\text { within the past } 30 \text { days }\end{array}$} & Yes & $14(77.8 \%)$ & $27(64.3 \%)$ & $1.94(0.542-6.979)$ & 0.308 \\
\hline & No & $4(22.2 \%)$ & $15(35.7 \%)$ & 1 & \\
\hline \multirow{2}{*}{$\begin{array}{l}\text { How many days do you eat } \\
\text { fruits }\end{array}$} & $<5$ days & $45(88.2 \%)$ & $108(69.7 \%)$ & $3.26\left(1.303-8.175^{*}\right.$ & 0.012 \\
\hline & $\geq 5$ days & $6(11.8 \%)$ & $47(30.3 \%)$ & 1 & \\
\hline \multirow{2}{*}{$\begin{array}{l}\text { Servings of fruit do you eat on } \\
\text { one of those days }\end{array}$} & $<5$ servings & $46(97.9 \%)$ & $145(94.8 \%)$ & $2.5(0.309-20.832)$ & 0.386 \\
\hline & $\geq 5$ servings & $1(2.1 \%)$ & $8(5.2 \%)$ & 1 & \\
\hline \multirow{2}{*}{$\begin{array}{l}\text { How many days do you eat } \\
\text { vegetables }\end{array}$} & $<5$ days & $46(90.2 \%)$ & $121(78.1 \%)$ & $2.58(0.953-7.015)$ & 0.062 \\
\hline & $\geq$ 5days & $5(9.8 \%)$ & $34(21.9 \%)$ & 1 & \\
\hline \multirow{2}{*}{$\begin{array}{l}\text { Servings of vegetables do you } \\
\text { eat on one of those days }\end{array}$} & $<5$ servings & $40(88.9 \%)$ & $119(78.3 \%)$ & $2.22(0.811-6.070)$ & 0.121 \\
\hline & $\geq 5$ servings & $5(11.1 \%)$ & $33(21.7 \%)$ & 1 & \\
\hline \multirow{3}{*}{$\begin{array}{l}\text { Type of oil or fat is most often } \\
\text { used for meal preparation in } \\
\text { your household }\end{array}$} & $\begin{array}{l}\text { Vegetable } \\
\text { oil }\end{array}$ & $13(25.5 \%)$ & $54(34.8 \%)$ & $1.31(0.613-2.813)$ & 0.483 \\
\hline & Butter & $16(31.4 \%)$ & $36(23.2 \%)$ & $0.71(0.328-1.544)$ & 0.389 \\
\hline & Margarine & $22(43.1 \%)$ & $65(41.9 \%)$ & 1 & \\
\hline \multirow[t]{2}{*}{ Vigorous work related activity } & Yes & $6(27.8 \%)$ & $23(14.8 \%)$ & 1 & \\
\hline & No & $45(88.2 \%)$ & $132(85.2 \%)$ & $1.3(0.5-3.413)$ & 0.585 \\
\hline \multirow[t]{2}{*}{ Moderate work related activity } & Yes & $14(27.5 \%)$ & $35(22.6 \%)$ & 1 & \\
\hline & No & $37(72.5 \%)$ & $120(77.4 \%)$ & $0.919(0.45-1.87)$ & 0.817 \\
\hline \multirow{2}{*}{$\begin{array}{l}\text { walk or use a bicycle physical } \\
\text { activity }\end{array}$} & Yes & $25(49.0 \%)$ & $87(56.1 \%)$ & 1 & \\
\hline & No & $26(51.0 \%)$ & $68(43.9 \%)$ & $1.33(0.706-2.51)$ & 0.377 \\
\hline \multirow[t]{2}{*}{ Vigorous recreational activity } & Yes & $8(22.9 \%)$ & $30(19.4 \%)$ & 1 & \\
\hline & No & $43(84.3 \%)$ & $125(80.6 \%)$ & $1.29(0.549-3.028)$ & 0.559 \\
\hline \multirow{2}{*}{$\begin{array}{l}\text { Moderate recreational } \\
\text { Activity }\end{array}$} & Yes & $18(35.3 \%)$ & $45(29.0 \%)$ & 1 & \\
\hline & No & $33(64.7 \%)$ & $110(71.0 \%)$ & $0.75(0.383-1.467)$ & 0.401 \\
\hline \multirow{2}{*}{$\begin{array}{l}\text { How much time do you spend } \\
\text { sitting on a typical day? }\end{array}$} & $<10 \mathrm{hr} /$ day & $10(19.6 \%)$ & $48(31.0 \%)$ & 1 & \\
\hline & $\geq 10 \mathrm{hr} /$ day & $41(80.4 \%)$ & $107(69.0 \%)$ & $1.8(0.851-3.975)$ & 0.121 \\
\hline \multirow{3}{*}{ Level of physical activity } & Low & $19(67.9 \%)$ & $32(28.1 \%)$ & $4.2(1.092-15.814)^{*}$ & 0.037 \\
\hline & Moderate & $6(21.4 \%)$ & $61(53.5 \%)$ & $0.69(0.158-3.000)$ & 0.619 \\
\hline & High & $3(10.7 \%)$ & $21(18.4 \%)$ & 1 & \\
\hline
\end{tabular}

$*=\mathrm{P}<0.05$ (significance level), $1=$ Reference

Determinants of overweight among government employees, in gibe district.

Predictor variables which had determinant effect on overweight in bivariate analysis were age, gender, marital status, exposed to tobacco smoking at your home or workplace, number of days do you eat fruits, servings of vegetables do you eat on one of those days, number of days do eat vegetables, sedentary behavior and level of physical activity. (Table 4) 
Table: 4 Bivariate binary logistic regression analysis, predictor variables associated with overweight among government employees in gibe district, Southern Ethiopia, 2016

\begin{tabular}{|c|c|c|c|c|c|}
\hline \multirow[t]{2}{*}{ Variables } & \multirow[t]{2}{*}{ Categories } & Cases & Controls & \multirow[t]{2}{*}{$\operatorname{COR}(95 \% \mathrm{CI})$} & \multirow{2}{*}{$\begin{array}{l}\text { P- } \\
\text { Value }\end{array}$} \\
\hline & & No $(\%)$ & No $(\%)$ & & \\
\hline \multirow[t]{3}{*}{ Age group in years } & $20-34$ & $24(47.1 \%)$ & $97(62.6 \%)$ & 1 & \\
\hline & $35-44$ & $18(35.3 \%)$ & $50(32.3 \%)$ & $1.5(0.723-2.930)$ & 0.294 \\
\hline & $45+$ & $9(17.6 \%)$ & $8(5.1 \%)$ & $4.6(1.588-13.019)$ & 0.005 \\
\hline \multirow[t]{2}{*}{ Gender } & Female & $10(19.6 \%)$ & $59(38.1 \%)$ & 1 & \\
\hline & Male & $41(80.4 \%)$ & $96(61.9 \%)$ & $2.5(1.174-5.407)$ & 0.018 \\
\hline \multirow[t]{2}{*}{ Marital status } & Single & $20(39.2 \%)$ & $86(55.5 \%)$ & 1 & \\
\hline & Married & $31(60.8 \%)$ & $69(44.5 \%)$ & $1.9(1.013-3.683)$ & 0.045 \\
\hline \multirow{2}{*}{$\begin{array}{l}\text { Exposed to tobacco smoking at } \\
\text { your home or workplace }\end{array}$} & Yes & $20(39.2 \%)$ & $43(27.7 \%)$ & $1.7(0.866-3.261)$ & 0.125 \\
\hline & No & $31(60.8 \%)$ & $112(72.3 \%)$ & 1 & \\
\hline \multirow{2}{*}{$\begin{array}{l}\text { Number of days do you eat } \\
\text { fruits }\end{array}$} & $<5$ days & $45(88.2 \%)$ & $108(69.7 \%)$ & $3.26(1.303-8.175$ & 0.012 \\
\hline & $\geq 5$ days & $6(11.8 \%)$ & $47(30.3 \%)$ & 1 & \\
\hline \multirow{2}{*}{$\begin{array}{l}\text { Servings of vegetables do you } \\
\text { eat on one of those days }\end{array}$} & $<5$ servings & $40(88.9 \%)$ & $119(78.3 \%)$ & $2.22(0.811-6.070)$ & 0.121 \\
\hline & $\geq 5$ servings & $5(11.1 \%)$ & $33(21.7 \%)$ & 1 & \\
\hline \multirow{2}{*}{$\begin{array}{l}\text { Number of days do eat } \\
\text { vegetables }\end{array}$} & $<5$ days & $46(90.2 \%)$ & $121(78.1 \%)$ & $2.58(0.953-7.015)$ & 0.062 \\
\hline & $\geq 5$ days & $5(9.8 \%)$ & $34(21.9 \%)$ & 1 & \\
\hline \multirow[t]{2}{*}{ Sedentary behavior } & $<10 \mathrm{hr} /$ day & $10(19.6 \%)$ & $48(31.0 \%)$ & 1 & \\
\hline & $\geq 10 \mathrm{hr} /$ day & $41(80.4 \%)$ & $107(69.0 \%)$ & $1.8(0.851-3.975)$ & 0.121 \\
\hline \multirow[t]{3}{*}{ Level of physical activity } & Low & $19(67.9 \%)$ & $32(28.1 \%)$ & $4.2(1.092-15.814)$ & 0.037 \\
\hline & Moderate & $6(21.4 \%)$ & $61(53.5 \%)$ & $0.69(0.158-3.000)$ & 0.619 \\
\hline & High & $3(10.7 \%)$ & $21(18.4 \%)$ & 1 & \\
\hline
\end{tabular}

Independently Determinants associated with overweight among government employees.

The Variables which has independently significant association with overweight among government employees were age, gender and level of physical activity. (Table 5)

Table: 5 Final multivariable binary logistic regression model risk factors independently associated with overweight among government employees in gibe district, Southern Ethiopia, 2016

\begin{tabular}{|c|c|c|c|c|c|c|}
\hline \multirow[t]{2}{*}{ Variables } & \multirow[t]{2}{*}{ Categories } & Cases & Controls & \multirow{2}{*}{$\begin{array}{c}\text { Crude OR } \\
(95 \% \mathrm{CI})\end{array}$} & \multirow[t]{2}{*}{$\operatorname{AOR}(95 \% C I)$} & \multirow{2}{*}{$\begin{array}{l}P \text { - } \\
\text { value }\end{array}$} \\
\hline & & No (\%) & No $(\%)$ & & & \\
\hline \multirow{3}{*}{$\begin{array}{l}\text { Age group in } \\
\text { year }\end{array}$} & $20-34$ & $24(47.1 \%)$ & $97(62.6 \%)$ & 1 & 1 & \\
\hline & $35-44$ & $18(35.3 \%)$ & $50(32.3 \%)$ & $1.5(0.723-2.930)$ & $1.6(0.566-4.574)$ & 0.372 \\
\hline & $\geq 45$ & $9(17.6 \%)$ & $8(5.1 \%)$ & $4.6(1.588-13.019)$ & $6.3(1.503-26.621)^{*}$ & 0.012 \\
\hline \multirow[t]{2}{*}{ Gender } & Female & $10(19.6 \%)$ & $59(38.1 \%)$ & 1 & 1 & \\
\hline & Male & $41(80.4 \%)$ & $96(61.9 \%)$ & $2.5(1.174-5.407)$ & $3.5(1.044-11.957)^{*}$ & 0.043 \\
\hline \multirow{3}{*}{$\begin{array}{ll}\text { Level } & \text { of } \\
\text { physical } & \\
\text { activity } & \end{array}$} & Low & $19(67.9 \%)$ & $32(28.1 \%)$ & $4.2(1.092-15.814)$ & 4.6(1.100-19.119)* & 0.037 \\
\hline & Moderate & $6(21.4 \%)$ & $61(53.5 \%)$ & $0.69(0.158-3.000)$ & $0.9(0.18-4.078)$ & 0.853 \\
\hline & High & $3(10.7 \%)$ & $21(18.4 \%)$ & 1 & 1 & \\
\hline
\end{tabular}

$*=\mathrm{P}<0.05$ (significance level), $1=$ Reference

Male gender employees were 3.5 times more likely to develop overweight compared to females (AOR: 3.5, 95\%CI: 1.044-11.957). Likewise, those who had age group 45 and above were 6.3 times more likely to develop overweight compared to those had age group 20-34 years old (AOR=6.3, 95\%CI: 1.503-26.621).Level of physical activity was main determinant factor to prevent risk of develop overweight. Employees with low level physical activity about overweight were 4.6 times more likely to develop overweight compared to those having high level physical activity (AOR: 4.6, 95\%CI: 1.100-19.119).

\section{Discussion}

After handling other confounding factors age, gender and level of physical activity were found to be determinant factors for risk of overweight.

Findings from this study show that, the odds of overweight increased about 3.5 times comparing employees who were men to those who were females(AOR: 3.5, 95\%CI: 1.044-11.957). This finding is in line with study conducted in Turkey (25) and in Nigeria (26) showed male gender of employees significant association with increasing risk of overweight. In contrast study conducted in Ghana (24) and South Africa (27) showed that male gender was inversely associated with overweight. This is could be due to biological bases, frequency of eating food prepared outside the home and social pressure to pay greater attention to their weight. 
In the current study, age was one of the risk factor that predisposes an individual to development of overweight. Employees who were age greater than or equal to 45 years old 6.3 times more likely to develop overweight compared to those had age group 20-34 years old (AOR: 6.3, 95\%CI: 1.503-26.621).This finding is supported study done in Brazil (28), Nigeria (26), Turkey (25) and Ghana (24) showed age significant association with increasing risk of overweight. This is could be due to advancing age results in slowing of the metabolic processes and reduced physical activity.

Low level physical activity was one of the most important risk factors for overweight identified in this study. Accordingly, Employees who were low level of physical activity 4.6 times more likely to develop overweight in comparison to participants who were high level physical activity (AOR: 4.6, 95\%CI: 1.100-19.119). This finding is in agreement with the study done in Ghana (24), in Turkey (25) and in Ghana (29) showed physical activity significant associations with increasing level of physical activity to decreases risk of develop overweight. This is could be due to lack of willingness to do the physical exercise, no time for physical exercise and low inter-sectoral collaboration in promoting physical exercise.

Strength of this study is an original study in this particular study area that paves a way and expected to generate base line information for the one who needs to conduct another assessment. Limitation of this study is risk of recall bias, especially, in behavioral risk factors.

\section{Conclusion and Recommendation}

\section{Conclusion:}

Government employees of Gibe District had old age group, male gender and low physical activity that lead to increased risk of overweight. These are modifiable and non- modifiable risk factors; therefore increased awareness about physical activity will be effective control measure.

\section{Recommendations:}

Based on the findings obtained from this study, a number of recommendations are made under the following: For employers:

* Older age employees should be frequently get screened for overweight and need to be informed of results so they can improve their life style.

* All segments of study population practicing low level physical activities should be motivated to exercise physical activities of varying intensity based on their capacity and health status.

* Awareness creation interventions aimed at reducing overweight should especially target the men and older employees.

\# The perceptions of the employees about body size and shape should be improved to build positive attitudes that ultimately encourage exercise of physical activities through different awareness-creation mechanisms

For sectors:

\# Recreational/sports-related physical activities should be promoted and opportunities should be created and facilitated by different sectors to enable the employee's practice of sports- related physical activities.

\# Promote the health benefits of physical activities including work, transport and leisure time related activities of various intensities in the general so that the risk of developing overweight will be markedly reduced.

Further Research

* Assessment of knowledge, attitude and practices towards risk factors of overweight should be conducted.

List of Abbreviations

BMI Body Mass Index

BWS Body weight status

EDHS Ethiopian Demographic and Health Survey

MET Metabolic equivalent

NCDs Non Communicable Diseases

OR Odds Ratios

SNNPR Southern Nation Nationalities and People Region

WHO World Health Organization

\section{Acknowledgments}

Firstly, we would like to gratitude our heartfelt thanks to Jimma University College of health sciences department of epidemiology for funding this study.

Lastly, we would like to acknowledge Gibe District study participants and supervisors for their participation and corporation. 


\section{Declaration}

Funding: Jimma University funded this study.

Conflict of Interest: All authors declared as there was no conflict of interest.

Data availability: data is available and provided on the request

\section{References}

1. Horton T, Brachey A, Reed G, Peters J, Hill J, Fat and carbohydrate overfeeding in humans: different effects on energy storage. Am J Clin Nutr, 1995. 62: p. 19-29.

2. Sims EA, Expenditure and storage of energy in man. J Clin Invest, 1987. 1019: p. 79.

3. Fonseca M ,djmdF, Chor D, Lopes C, Andreozzi V, Overweight and obesity and associated factors. RBCDH, 2006. 22(11): p. 2359-67.

4. Marie N, Margaret R, Blake T, Nicholas G, Christopher M, et al, Global, regional, and national prevalence of overweight and obesity in children and adults during 1980-2013. a systematic analysis for the Global Burden of Disease Lancet, 2014. 384: p. 76681.

5. Garenne M, Urbanisation and child health in resource poor settings with special reference to under-five mortality in Africa. . Arch Dis Child, 2010. 95: p. 464-8.

6. Ziraba A, Ochako R, Overweight and obesity in urban Africa: A problem of the rich or the poor? BMC Public Health, 2009.9 p. 465.

7. Martins $\mathrm{C}$, Truby $\mathrm{H}$, A review of the effects of exercise on appetite regulation: an obsity perspective. Int $\mathrm{J}$ Obes, 2008. 32(9): p. 1337-1347.

8. WHO, Obesity and overweight 2015.

9. Riley NM, Cooper L, Schreiner P, Smith DE, Sorlie P, et al, Relation of self-image to body size and weight loss attempts in black women. Am J Epidemiol, 1998. 148: p. 1062-8.

10. Flynn KJ,Body images and obesity risk among black females. Ann Behav Med, 1998. 20 p. 13-24.

11. Park E, Overestimation and underestimation: adolescents' weight perception in comparison to BMI-based weight status and how it varies across socio-demographic factors. J Sch Health, 2011. 81: p. 57-64.

12. Wardle J,Binge eating: a theoretical review. Br J Clin Psychol, 1981. 20: p. 97-109.

13. Spiegel A,Executive summary of the strategic plan for National Institutes of Health Obesity Research. Am. J. Clin. Nutr, 2005. 82: p. 2115-2145.

14. SniehottaF, DombrowskiA, Avenell, M. Johnston and S. McDonald et al, Randomised controlled feasibility trial of an evidence-informed behavioural intervention for obese adults with additional risk factors. PLoS One, 2011. 6.

15. Standler K, Dietary Intake, Physical Activity and Risk for Chronic Diseases of Lifestyle Among Employees. International Journal of Advanced Nursing Studies, 2006. 4(2): p. 85-93.

16. Central Statistical Agency, Ethiopia Demographic and Health Survey. Addis Ababa, Ethiopia. Calverton, Maryland, USA; , 2011.

17. WHO, Obesity: preventing and managing the global epidemic. World Health Organ Tech Rep, 2000. 894 p. $1-253$.

18. WHO (World Health Organization), Preventing chronic diseases. A vital investment, Geneva, 2005

19. Victora CG, Fall C, Hallal PC, Martorell R, Richter L, Sachdev HS, Maternal and child under nutrition: Consequences for adult health and human capita. Lancet, 2008. 371 (9609)p. 340-357.

20. Campbell T, Emerging disease burdens and the poor in cities of the developing world. J. Urban Health, 2007. 84 (3) p. 54-64.

21. Kamadjeu RM, Atanga JS, Kiawi EC, Unwin N, Mbanya JC, Anthropometry measures and prevalence of obesity in the urban adult population of Cameroon: an update from the Cameroon Burden of Diabetes Baseline Survey. BMC Public Health 2006. 6: p. 228.

22. WHO (World Health Organization), Reducing Risks, Promoting Healthy Life. The World Health Report,Geneva, 2002.

23. National population census commission of Ethiopia, 2007

24. Prince N, Samuel O, Patricia A, and Bismark S,Prevalence of obesity and overweight and associated factors among financial institution workers. BMC Res, 2015. 599: p. 18.

25. Edibe P, Birsen D, Yasemin A,perevalence and risk factors of overweight and obesity. 2009. 40(6): p. 13061314.

26. Sandra I, Foluke O, Michael O, Ukandu O, Anas S, Olufemi F,Obesity among health service providers in Nigeria: . The Pan African Medical Journal., 2015. 22(1).

27. Skaal L,Obesity and health problems among South African health care workers S AfrFam Pract, 2011. 53(6) p. 563-567.

28. Juliane B, Giseli M,Overweight and obesity and associated factors in technical and administrative staff Revbras. cineantropom2013. 15(5). 
29. Charles D, Prosper A, Francis B, Assessment of Overweight and Obesity Prevalence Among Practicing Nurses and Midwives in the Hohoe Municipality of the Volta Region. 2015. 3(6): p. 842-851. 